\title{
The Correlation of Age, Nutritional Status, Working Posture and Musculoskeletal Disorders in PT ARPS
}

\section{Hubungan Umur, Status Gizi, dan Postur Kerja dengan Keluhan Muskuloskeletal di PT ARPS}

\author{
Mufidha Khoirul Umami \\ Petrokimia Gresik Hospital \\ Jalan Jend. A. Yani 69 Gresik Subdistrict, Gresik, East Java 61119, Indonesia
}

\begin{abstract}
Introduction: Musculoskeletal disorders occur due to various factors: main factors, such as extortion of the muscles, repetitive activities, non-ergonomic working postures; secondary factors (pressure, vibrant, microclimate), and individual factors (age, years of service, sex, nutritional status, physical endurance, smoking habits, physical strength and anthropometry). The workers in the Injection Department of PT ARPS mostly work with non-ergonomic working postures. The aim of this study is to analyze the correlation between age, nutritional status, and working postures as well as the complaints on musculoskeletal disorders among the workers in the Injection Department of PT ARPS. Methods: This study applies an analytic observational method with a cross-sectional design. The sample is selected by implementing simple random sampling with a total of 52 respondents. The data collection to measure the ratio risk level of the working postures of the injection workers is completed by using Rapid Upper Limb Assessment (RULA) measurement method, while Nordic Body Map (NBM) questionnaire form is used to measure risk level of the disorder, and anthropometry measurement is applied to evaluate the nutritional status of the workers, such as their height and weight. The data are analyzed using Spearman Rho's Correlation (significance level $\alpha=5 \%$ ). Results: It was found that there were 76.9\% injection workers who are $<35$ years old, $59.6 \%$ who have normal nutritional status, 27 or $51.9 \%$ have low musculoskeletal disorders, and 19 or $36.5 \%$ have low-risk postures. Conclusion: that there is a correlation between age $(\rho$-value $=0.005)$, nutritional status $(\rho$-value $=0.003)$, working postures $(\rho$-value $=0.036)$ and musculoskeletal disorders on the injection workers at PT ARPS.
\end{abstract}

Keywords: injection worker, musculoskeletal disorders, Nordic Body Map, Rapid Upper Limb Assessement, working postures

\section{ABSTRAK}

Pendahuluan: Keluhan muskuloskeletal dapat terjadi karena beberapa faktor pemicu yang terdiri dari peregangan otot yang berlebihan, aktivitas berulang, postur kerja yang tidak ergonomi, faktor sekunder (tekanan, getaran, mikroklimat), dan faktor individu (umur, masa kerja, jenis kelamin, status gizi, kesegaran jasmani, kebiasaan merokok, kekuatan fisik dan ukuran tubuh). Pekerja pada bagian Injection di PT. ARPS sebagian besar bekerja dengan postur kerja yang tidak ergonomi. Penelitian ini bertujuan untuk menganalisis hubungan antara umur, status gizi, dan postur kerja dengan keluhan muskuloskeletal pada bagian injection di PT. ARPS. Metode: Penelitian ini bersifat observasional analitik dengan jenis penelitian cross sectional. Perhitungan sampel menggunakan simple random sampling dengan jumlah sampel sebanyak 52 orang. Pengambilan data untuk mengukur tingkat risiko postur tubuh pekerja injection dengan menggunakan metode pengukuran Rapid Upper Limb Assessement (RULA), lembar kuesioner Nordic Body Map (NBM) untuk mengukur tingkat risiko keluhan, dan pengukuran antropometri untuk mengukur status gizi pekerja seperti tinggi dan berat pekerja. Data diolah dengan uji statistik Spearman Rho's Correlation (tingkat signifikansi $\alpha=5 \%$ ). Hasil: Menunjukan bahwa persentasi umur pekerja di bawah 35 tahun (76,9\%), mempunyai status gizi normal (59,6\%), sebanyak 27 pekerja (51,9\%) mengalami keluhan muskuloskeletal rendah dan 19 pekerja lainnya (36,5\%) memiliki risiko postur kerja dengan kategori rendah. Simpulan: Terdapat hubungan antara umur ( $\rho$-value $=0,005)$, status gizi $(\rho$-value $=$ $0,003)$ dan postur kerja $(\rho$-value $=0,036)$ dengan keluhan muskuloskeletal pada pekerja bagian injection di PT. ARPS.

Kata kunci: keluhan muskuloskeletal, Nordic Body Map, pekerja injection, postur kerja, Rapid Upper Limb Assessement

C2019 IJOSH All right reserved. Open access under CC BY NC-SA license doi: 10.20473/ijosh.v8i3.2019. 283-291 Received June 25, 2018, received in revised form September 06, 2018, Accepted November 04, 2019, Published: December 2019 
Author for Correspondence:

Mufidha Khoirul Umami

Email:mufidhaku@gmail.com

Telephone: +6281285077494

\section{INTRODUCTION}

As the years go by, various worldwide industrial sectors even in Indonesia are growing rapidly. Moreover, many industries have been supported by the usage of sophisticated machines technology. It closely relates to work environments that are comfortable and safe. A comfortable and safe work environment aims to regulate how the work will be carried out, including the working postures of workers. These environments refer to ergonomic work conditions.

Ergonomic is a discipline of science, art, and technology that aims to balance human capabilities with the limitations they have when they are active or at rest to be in prime or optimal conditions (Tarwaka, Bakri and Sudiajeng, 2004).

Nonetheless, in its implementation, the ergonomic imbalance can also occur if the existing work environment and the condition of the worker's body are in forced or uncomfortable working postures. It has an impact on the risk of musculoskeletal disorders (MSDs) for workers who work on particular machines. The MSDs complaint is the muscular complaint felt by the workers when they are in non-ergonomic working conditions and the impact can be directly or indirectly felt by them. If MSDs are not treated immediately, it will cause damage to the tendons, ligaments, and joints (Tarwaka, Bakri and Sudiajeng, 2004).

Apart from non-ergonomic working conditions, the complaints on MSDs can also be caused by several other factors, such as excessive muscle stretching, repetitive activities, non-ergonomic working postures. In addition, there are secondary factors (pressure, vibration, microclimate), and individual factors (age, years of service, sex, nutritional status, smoking habits, and body posture).

There are a lot of data associated with MSDs regarding those factors. Bestowing to The Bureau of Labor Statistics (2016), musculoskeletal accidents, such as sprains and strained muscles due to excessive lifting in 2015 were reported as many as 356,910 cases or $31 \%$ and resulted in 12 days lost for the recovery process. Whereas, according to WorkRelated Musculoskeletal Disorders (WRMSDs), in Australia, from 2009-2014 there were 360,180 workers who experienced serious MSDs in the form of back pain, lumbago, and sciatica.

Referring to the Ministry of Health of the Republic of Indonesia (2009), musculoskeletal diseases and connective tissues include in the 10 most outpatient disease at the hospital. In 2008, there were 605 patients died from a total of 26,897 patients suffering from MSDs and connective tissue diseases. In 2013, Basic Health Research disclosed that joint diseases or MSDs were the second-highest non-communicable disease after hypertension with a prevalence rate of $11.9 \%$.

Several studies are noticed to complement those data. One of them is the study conducted by Umami, Hartanti and Sujoso (2014) the written batik workers in Jember. As a result, they discovered that there were 33 workers out of a total of 36 workers who suffered from lower back pain. Lower back pain is also significantly related to the workers' age, years of service, nutritional status, and work attitudes.

Another study was the one carried out by Jalajuwita and Paskarini (2015) on the welding workers at PT X Bekasi, which showed that all workers experienced MSDs with the majority of them were suffering from moderate-risk complaints $(62.5 \%)$. Furthermore, Jalajuwita affirmed that it is indicated a significant correlation between working postures and MSDs.

PT ARPS is an industry engaging in manufacturing with the main raw materials in the form of plastic. This industry produces various plastic packages, such as plastic bottles, powder pans, toothpaste caps, and so on. Occupational safety and health risks that can be caused by this work are non-ergonomic working postures due to the exposure of the workers to high-tech machines without the support of adequate facilities, for example, ergonomic chairs and tables. In regard to this, the workers in the injection department who control and treat the product produced by the machine have the most risk of suffering from MSDs. In addition, the injection workers must sit for 8 hours with an uncertain break.

The purpose of this study is to analyze the correlation between age, nutritional status, and working posture and MSDs complaints experienced by the workers in the injection department.

\section{METHODS}

This study applied analytic observational research design along with the cross-sectional design. The sample was calculated by a simple 
random sampling formula and there was a total sample of 52 respondents. The data was collected from March 2018 to April 2018. The dependent variable was the MSDs complaints experienced by the workers, while the independent variables were the age, nutritional status, and the working postures of the workers during working time.

The data of the study was obtained through observations in the form of observing the working postures made by the injection workers, which later was analyzed by using the Rapid Upper Limb Assessment (RULA) method. The RULA method included Group A; the measurements of the upper arm, forearm, and wrist and Group B; the measurement of the neck, body, and legs. The measurement results of each group were calculated in tables A and B. The final results of the calculation were recalculated in table $\mathrm{C}$ and the result was labeled as the final scores with the category of ergonomic risk, starting from low (1-2), moderate (3-4), high (5-6), and very high (7).

The Nordic Body Map (NBM) questionnaire was filled by the respondents to find out the risk level of MSDs felt by the workers. Meanwhile, the anthropometry measurement was done by measuring the height and weight of the workers to determine the workers' nutritional status through their Body Mass Index (BMI).

Next, after the data had been obtained, it was processed and analyzed by using the Spearman Rho's Correlation statistical test with a significance level of $\alpha=0.05$. The data were processed by using the statistical test aimed to identify whether there is a correlation between the dependent and independent variables and whether there is a correlation coefficient of each variable that correlates each other.

\section{RESULTS}

\section{Company Overview}

PT ARPS is a manufacturing industry that produces containers with main raw materials in the form of plastic. PT ARPS has a total of 491 employees, which amongst them, 241 employees are contracted workers and 250 employees are subcontracted workers.

The production process at PT ARPS is divided into three main parts: molding, assembly, and decoration (Surface Treatment). The molding production process consists of injection molding and extrusion blow molding. While in the assembly production process, there are manual assembly process, semi-auto assembly, and rotary assembly. Furthermore, the decoration production process consists of the hot transfer process, hot side, silk screen printing, labeling/printing, and pad printing. In completing these three main production processes, the workers at PT ARPS is also supported by several facilities, namely mold maintenance, spare part fabrication, and hot stamping dies fabrication. The operation of PT ARPS is done every day for 24 hours and is divided into 4 shifts.

One part of the production process in molding production is injection molding. Injection molding is a process for making several products, such as powder pits, toothpaste containers, facial cleansing bottle caps, and so on. For this production process, PT ARPS provides 43 machines which are used to support the manufacturing process of these products. The machines are then used by the injection workers who are supervised by the operators. The workers in the injection department have a duty to sort all of the products produced by the machine before being distributed to the consumers. Worth selling products will be put into a cardboard box and distributed directly to consumers. Other worth selling products with the plastic fibers will be processed by cutting the plastic fibers using a cutter. The same treatment is also given to facial cleansing bottle caps, the cap holes will be smeared with lotion or lubricant

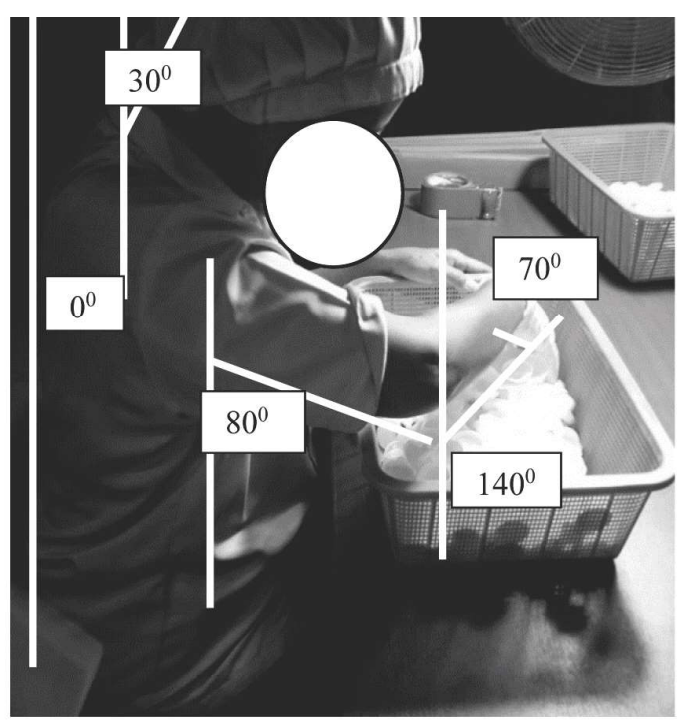

Figure 1. The worker in the injection department at PT ARPS on March 2018 with a moderate-risk category 
Table 1. Frequency Distribution of the Respondents based on the Age in the Injection Department at PT ARPS in March 2018

\begin{tabular}{ccc}
\hline Age (Years old) & Frequency (n) & Percentage (\%) \\
\hline$<35$ & 40 & 76.9 \\
$35-40$ & 7 & 13.5 \\
$>40$ & 5 & 9.6 \\
\hline Total & 52 & 100 \\
\hline
\end{tabular}

Table 2. Frequency Distribution of the Respondents based on the Nutritional Status in the Injection Department at PT ARPS in March 2018

\begin{tabular}{ccc}
\hline Nutritional Status & Frequency (n) & Percentage (\%) \\
\hline Underweight & 7 & 13.5 \\
Normal & 31 & 59.6 \\
Overweight & 14 & 26.9 \\
\hline Total & 52 & 100 \\
\hline
\end{tabular}

Table 3. Frequency Distribution of the Respondents based on the Working Postures in the Injection Department at PT ARPS in March 2018

\begin{tabular}{ccc}
\hline Risk Level & Frequency (n) & Percentage (\%) \\
\hline Level 2 (Medium) & 19 & 36.5 \\
Level 3 (High) & 16 & 30.8 \\
Level 4 (Very High) & 17 & 32.7 \\
\hline Total & 52 & 100 \\
\hline
\end{tabular}

to prevent difficulties when opening the bottles. Products that are not worth selling will then be put in a container labeled as "rejected" and will be crushed again into plastic, to be made into the original product.

\section{Frequency Distribution of Age, Nutritional Status, and Working Postures in the Injection Department}

Table 1 showed that the age was divided into 3 groups; $<35$ years old, $35-40$ years old, and $>40$ years old. From the three groups, the majority of workers belonged to the age group of $<35$ years old, which was as much as $76.9 \%$.

Table 2 disclosed that the nutritional status is divided into 3 groups; underweight $(<18.4 \mathrm{BMI})$, normal (18.5-25 BMI), and overweight ( $>25 \mathrm{BMI})$
Table 4. RULA Assessment on Group A of the Workers in the Injection Department at PT ARPS in March 2018

\begin{tabular}{ccc}
\hline Body Posture & Angle & Score \\
\hline Upper arm & flexion 800 & +3 \\
Forearm & flexion 1400 & +2 \\
Wrist & flexion 700 & +3 \\
Twist & & +1 \\
\hline \multicolumn{2}{c}{ Table A } & 4 \\
\hline
\end{tabular}

Table 5. RULA Assessment on Group B of the Workers in the Injection Department at PT ARPS in March 2018

\begin{tabular}{ccc}
\hline Body Posture & Angle & Score \\
\hline Neck & flexion 300 & +3 \\
Body & flexion $\geq 900$ & +1 \\
Feet sole & Supported & +1 \\
\hline \multicolumn{2}{c}{ Table B } & 3 \\
\hline
\end{tabular}

Table 6. RULA Assessment on Group A of the Workers in the Injection Department at PT ARPS in March 2018

\begin{tabular}{ccc}
\hline Body Posture & Angle & Score \\
\hline Upper arm & flexion 500 & +3 \\
Forearm & flexion 450 & +2 \\
Wrist & flexion 50 & +2 \\
Twist & & +1 \\
\hline \multicolumn{2}{c}{ Table A } & 4 \\
\hline
\end{tabular}

(Nutrition Guidelines, 2011). From the three groups, it can be seen that as much as $59.6 \%$ of the workers were in the normal nutritional status.

The measurement of the ergonomic risk level of the workers in the injection department was carried out by using the Rapid Upper Limb Assessment (RULA) method. The measurement results produced a score that was converted into Table $\mathrm{C}$, then was analyzed and categorized into four levels; level 1 (low), level 2 (moderate), level 3 (high), and level 4 (very high).

Table 3 indicated that evenly the workers in the injection department attained the scores on working posture at level 2 (moderate ) to level 4 (very high). Nevertheless, $36.5 \%$ of the workers were in the working postures with an ergonomic risk level 2 (moderate ). The example of a photo analysis on 
the worker's posture in the Injection Department at PT ARPS by using the RULA method is shown in figure 1.

The measurements of the upper arms, forearms, and wrist are named as mentioned in Table A which results attained a score of 4 . The scores in Table A were added by +1 on muscle use because the posture was done repetitively more than $4 \mathrm{x}$ per minute. In addition, it was given +0 on the score of loading and exertion because of the unavailability of resistance and erratically exertion of $<2 \mathrm{~kg}$. Thus, the total score of Group A was 5.

The measurements of the neck, body, and feet sole are named as mentioned in Table B and produced a score of 3 . Table $\mathrm{B}$ value has added a score of +0 on muscle use because the posture was not done repetitively more than $4 \mathrm{x}$ per minute and the worker did not work in a static state within $>1$

Table 7. RULA Assessment on Group B of the Workers in the Injection Department at PT ARPS in March 2018

\begin{tabular}{ccc}
\hline Body Posture & Angle & Score \\
\hline Neck (twisted) & flexion 200 & +3 \\
Body (twisted) & flexion 200 & +3 \\
Feet sole & Supported & +1 \\
\hline \multicolumn{2}{c}{ Table B } & 4 \\
\hline
\end{tabular}

Table 8. RULA Assessment on Group A of the Workers in the Injection Department at PT ARPS in March 2018

\begin{tabular}{ccc}
\hline Body Posture & Angle & Score \\
\hline Upper arm (Rotated) & flexion 150 & +2 \\
Forearm (crossed) & flexion $\geq 900$ & +2 \\
Wrist & flexion 50 & +2 \\
Twist & & +1 \\
\hline \multicolumn{2}{r}{ Table A } & 3 \\
\hline
\end{tabular}

Table 9. RULA Assessment on Group B of the Workers in the Injection Department at PT ARPS in March 2018

\begin{tabular}{ccc}
\hline Body Posture & Angle & Score \\
\hline Neck (twisted) & flexion 450 & +4 \\
Body (twisted) & flexion 500 & +5 \\
Feet sole & Supported & +1 \\
\hline \multicolumn{2}{c}{ Table B } & 7 \\
\hline
\end{tabular}

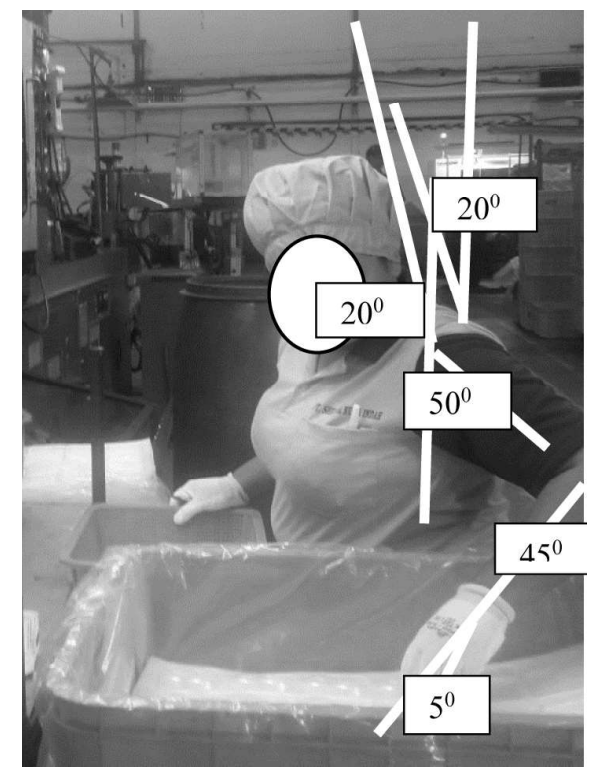

Figure 2. The Worker in the Injection Department at PT ARPS on March 2018 with a Highrisk Category

minute. On loading and exertion, the energy was given a score of +0 because the loading occurred erratically of $<2 \mathrm{~kg}$. For that reason, the total score obtained in Group B was 3.

Total scores in Groups A and B were converted into Table $\mathrm{C}$ and produced a final score of 4 . Based on the final score of the RULA method, the score was categorized as moderate. Therefore, further investigation, such as a change to improve work attitudes, is needed.

The measurements of the upper arms, forearms, and wrist were named as mentioned in Table A which has a score of 4 . Table A was added by +1 on muscle use because posture was repetitively done at more than $4 \mathrm{x}$ per minute, and was given a score of +1 on the loading and exertion of the workers because of the erratically lifting weight of 2-10 kgs. In the end, a total score obtained in Group A was 6.

The measurements of the neck, body, and feet sole were then named as mentioned in table B and produced a score of 4 . Table B values were added by +1 for the use of muscles and were given a score of +0 on loading and exertion and obtain a total score of 5 .

Total scores in Groups A and B were converted into Table $\mathrm{C}$ and produced a final score of 6 . The score belonged in the high category, which means that immediate investigation and corrective action must be done. 
Table 10. Frequency Distribution of the Levels of Musculoskeletal Disorders Complaints of the Workers in the Injection Department at PT ARPS in March 2018

\begin{tabular}{ccc}
\hline Level & Total & Percentage (\%) \\
\hline Low & 27 & 51.9 \\
Moderate & 24 & 46.2 \\
Very High & 1 & 1.9 \\
\hline Total & 52 & 100 \\
\hline
\end{tabular}

Table 11. Cross-Tabulation between the Age and the Level of Musculoskeletal Disorders of the Workers in the Injection Department at PT. ARPS in March 2018

\begin{tabular}{ccccc}
\hline \multirow{2}{*}{$\begin{array}{c}\text { Age } \\
\text { (years } \\
\text { old) }\end{array}$} & Low & Moderate & $\begin{array}{c}\text { Very } \\
\text { High }\end{array}$ & Total \\
\cline { 2 - 4 } & $\mathbf{n ( \% )}$ & $\mathbf{n ~ ( \% )}$ & $\mathbf{n}(\%)$ & $\mathbf{N}(\%)$ \\
\hline$<35$ & $25(62.5)$ & $24(35)$ & $1(2.5)$ & 40 \\
$35-40$ & $2(28.6)$ & $5(71.4)$ & $0(0)$ & 7 \\
$>40$ & $0(0)$ & $5(100)$ & $0(0)$ & 5 \\
\hline Total & $27(51.9)$ & $24(46.2)$ & $1(1.9)$ & 52 \\
\hline$\rho$ - value & \multicolumn{3}{c}{0.005} \\
\hline
\end{tabular}

The measurements of the upper arms, forearms, and wrist were named as mentioned in Table A which calculated and has a score of 3 . The value in table A was added by +1 for the use of muscles because the posture was repetitively carried out more than $4 x$ per minute, and given +1 for the loading and exertion of energy because of erratically lifting weights weighing 2-10 kg. Thus, in total, Group A obtained a score of 5 .

The measurements of the neck, body, and legs were then named as mentioned in Table $B$ and attained a score of 7 . Table $B$ values were added by +1 for the use of muscles and were given a score of +0 on loading and exertion, so the total score of Group B was 8. The total scores in Groups A and B were converted into Table $\mathrm{C}$ and produced a final score of 7. The score was noticed as a high category, indicating that there is a need for immediate investigation and corrective action.

The worker's complaints on MSDs can be assessed by using the Nordic Body Map (NBM) questionnaire. The assessment results of the questionnaire in the form of scores were added up and categorized as low, moderate, high, and very high complaints.

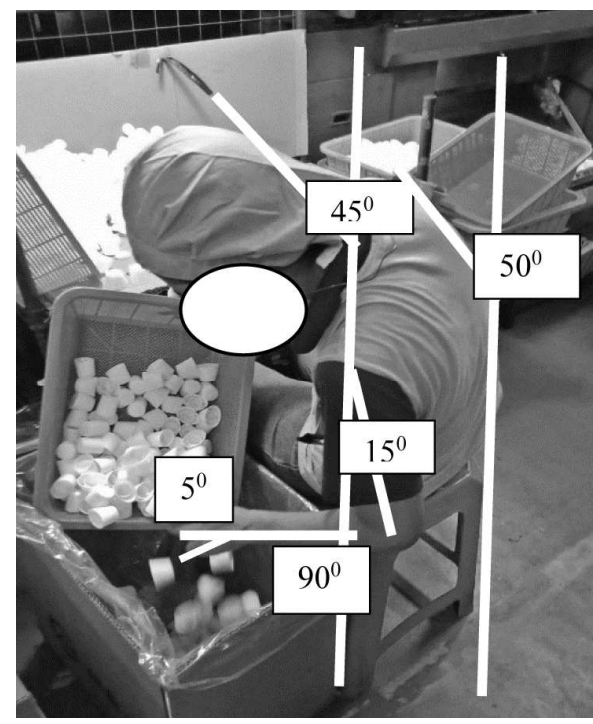

Figure 3. The Worker in the Injection Department at PT ARPS on March 2018 with a Very High-risk Category

Table 10 recorded that the MSDs complaints experienced by the workers were divided into three categories, namely low, moderate, and very high. The MSDs that are mostly experienced by the workers in the injection department considered as low-level of MSDs complaints, with a percentage of $51.9 \%$.

Correlation of Age, Nutritional Status, and Working Posture of the Workers in the Injection Department and the Complaints of Musculoskeletal Disorders.

Table 11 indicated that the workers aged $>40$ years old, that was as many as $100 \%$, experienced a moderate-level of MSDs. The Spearman Rho's correlation statistical test obtained $\rho$-value $<\alpha$, which implied that Ho was rejected. Thus, it can be concluded that there is a correlation between working posture and MSDs. The correlation coefficient value of these variables was 0.324 , indicating that the age and MSDs had a low correlation.

Table 12 disclosed that the workers with overweight nutritional status experienced a moderate-level of MSDs (85.7\%). The Spearman Rho's correlation test obtained the $\rho$-value $<\alpha$, indicated that Ho was rejected. Thus, it can be stated that there is a correlation between working postures and MSDs. Furthermore, the correlation coefficient value of these variables was 0.447 , which meant that the nutritional status and MSDs had a moderate level of correlation. 
Table 12. Cross-Tabulation between Working Postures and the Level of Musculoskeletal Disorders Complaints Experienced by Workers in the Injection Department at PT ARPS in March 2018

\begin{tabular}{ccccc}
\hline \multirow{2}{*}{$\begin{array}{c}\text { Nutritional } \\
\text { Status }\end{array}$} & Low & Moderate & $\begin{array}{c}\text { Very } \\
\text { High }\end{array}$ & Total \\
\cline { 2 - 4 } & $\mathbf{n}(\%)$ & $\mathbf{n}(\%)$ & $\mathbf{n}(\%)$ & $\mathbf{N}$ \\
\hline Underweight & $5(71.4)$ & $2(28.6)$ & $0(0)$ & 7 \\
Normal & $20(64.5)$ & $10(32.3)$ & $1(3.2)$ & 31 \\
Overweight & $2(14.3)$ & $12(85.7)$ & $0(0)$ & 14 \\
\hline Total & $27(59.9)$ & $24(46.2)$ & $1(1.9)$ & 52 \\
\hline$\rho$ - value & \multicolumn{4}{c}{0.003} \\
\hline
\end{tabular}

From Table 13, it can be seen that the workers who had a very high-risk of working posture had a moderate-level of MSDs (79.6\%). The Spearman Rho's correlation test obtained $\rho$-value $<\alpha$, so Ho was rejected. It can be concluded that there is a correlation between working posture and MSDs. The correlation coefficient value of these variables was 0.291 , indicating that the working posture and MSDs had a low-level of correlation.

\section{DISCUSSION}

Table 11 showed that most of the workers' age (76.9\%) in the Injection Department at PT ARPS ranges under 35 years old with a non-threatening age category and had a low-level of MSDs (62.5\%). The statistical test result indicated that there was a correlation between age and MSDs.

There was a correlation between the age and MSDs complaints experienced by the workers since those who are 35-40 years old experienced a moderate-level of MSDs (71.4\%), while $100 \%$ of the workers whose age is $>40$ years old experienced a moderate-level of MSDs. When the worker is at the age of $\geq 30$ years old, they are 4.4 times more likely to suffer from MSDs compared to the workers whose age is $<30$ years old (Rahayu, 2012). Consequently, it can be affirmed that the older the worker, the more MSDs complaints will be felt by the workers in the injection department.

The results of the study are in line with the study conducted by Septiani (2017) on the workers who work in the meat preparation department at PT. Bumi Sarimas Indonesia in 2017. The result of the statistical test was $\rho$-value $(0.000)<\alpha(0.05)$,
Table 13. Cross-Tabulation between Working Postures and the Level of Musculoskeletal Disorders Complaints Experienced by Workers in the Injection Department at PT ARPS in March 2018

\begin{tabular}{ccccc}
\hline \multirow{2}{*}{$\begin{array}{c}\text { Working } \\
\text { Posture }\end{array}$} & Low & Moderate & $\begin{array}{c}\text { Very } \\
\text { High }\end{array}$ & Total \\
\cline { 2 - 4 } & $\mathbf{n ( \% )}$ & $\mathbf{n}(\%)$ & $\mathbf{n}(\%)$ & $\mathbf{N}$ \\
\hline Moderate & $13(68.4)$ & $5(26.3)$ & $1(5.3)$ & 22 \\
High & $9(56.3)$ & $7(43.8)$ & $0(0)$ & 18 \\
Very High & $5(29.4)$ & $12(79.6)$ & $0(0)$ & 12 \\
\hline Total & $27(51.9)$ & $24(46.2)$ & $1(1.9)$ & 52 \\
\hline$\rho$ - value & \multicolumn{4}{c}{0.036} \\
\hline
\end{tabular}

specifying that there was a correlation between the age and MSDs complaints experienced by the workers. Another study conducted by Sari, Handayani and Saufi (2017) on the laundry workers also disclosed that the $\rho$-value $(0.005)<\alpha(0.05)$, which indicated a correlation between the age and working postures.

Moreover, the results of this study are also in accordance with the theory proposed by Tarwaka (2015), which proposed that generally, MSDs will be felt for the first time when the workers are at the age of 35 years old and the pain will increase gradually. It happens because, in middle-age phase, muscle strength and endurance will decrease and it increases the risk of experiencing MSDs.

Table 12 revealed that most of the nutritional status of the workers in the injection department at PT. ARPS was in the normal category $(59.6 \%)$ and had a low-level of MSDs (64.5\%). The statistical test results signified that there is a correlation between nutritional status and MSDs.

The majority of the workers were in the normal nutritional status category, yet some workers who had a nutritional status as the overweight category $(85.7 \%)$ experienced a moderate-level of MSDs. When compared to the workers who had underweight or normal nutritional status, those who had that status, only half of them experienced MSDs in moderate-level.

The results of this study are in accordance with the theory proposed by Tarwaka (2015), which stated that obese women have twice the risk of experiencing MSDs compared to underweight women. In other words, it can be affirmed that the 
more obese the workers, the higher the level of MSDs experienced by them.

Furthermore, the results of this study are also similar to the research conducted by Umami, Hartanti and Sujoso (2014) on written batik workers with the results of $\rho$-value $(0.003)<\alpha(0.05)$. They concluded that there is a correlation between nutritional status and MSDs. A similar study was also conducted by Kamurahan, Malonda and Sondakh (2018) on fishermen with $\rho$-value $(0.015)<\alpha(0.05)$ results and was concluded that there is a correlation between nutritional status and MSDs.

Table 13 explained that most of the working postures of the workers in the injection department at PT ARPS had a low to very high-level of ergonomic risks. All of the ergonomic risk levels included in the risky category and were necessary to have improvement.

The statistical test results on the working postures and MSDs calculated by using the Spearman Rho's correlation test resulted in $\rho$-value $<\alpha$. These results indicated that there is a correlation between working postures and MSDs.

The correlation occurred because the workers in the injection department who had moderate and high-level working postures experienced low-level of MSDs, while the workers with high-level of working postures experienced a moderate-level of MSDs. The workers with non-ergonomic working postures will experience an increase in MSDs (Arfiasari, 2014).

The non-ergonomic working postures are also supported by unaccommodating work facilities, such as unsuitable table height with the worker's anthropometry, non-backrest chairs for the workers to rest and the chair which height cannot be adjusted based on the worker's anthropometry. Zar (2012) explained that an inadequate or too low chair will affect an individual's body posture to bent forward and has uncomfortable ankles, while the lofty chair causes the pressure of the popliteal (back of the knee), which makes the blood flow lead to the leg area hampered and causing the tingle. Consequently, it can accelerate the occurrence of MSDs for the workers.

The results of the study are in accordance with the research conducted by Agustina (2017) on shoe craftsmen in Oso Wilangun Village, Surabaya. With the results of $\rho$-value $(0.000)<\alpha$ $(0.05)$, it was concluded that there is a correlation between working postures and MSDs. A similar study was also conducted by Nareshwari (2017) on PT. Pertamina EP Asse 2 Prabumulih Field with a correlation coefficient value of 0.444 , indicating the moderate-level of correlation between working postures and MSDs. Moreover, the results are also in accordance with the theory proposed by Tarwaka (2015), which claimed that one of the causes of MSDs is the non-ergonomic work attitude. It causes the movement from some part of the body to stray from its natural position. So, the more often the workers work in non-ergonomic positions, the higher the chance of MSDs will be felt.

\section{CONCLUSION}

After analyzing the data, it can be concluded that the workers in the injection department at PT ARPS are mostly $<35$ years old who have a normal nutritional status. Furthermore, the results of the working postures measurement using the Rapid Upper Limb Assessment (RULA) method disclosed that the workers have moderate-risk working postures. In the analysis of the correlation between the dependent and independent variables, there is a correlation of the age, nutritional status, working postures, and MSDs experienced by the workers.

\section{ACKNOWLEDGMENTS}

The authors would like to acknowledge the Faculty of Public Health of Universitas Airlangga for funding the sustainability of this study. In addition, the authors are thankful for PT ARPS and all respondents who have participated in this study.

\section{REFERENCES}

Agustina (2017) Hubungan Karakteristik Individu dan Posisi Kerja dengan Keluhan MSDs pada Pengrajin Sepatu di Kelurahan Tambak Oso Wilangun Surabaya. Undergraduate Thesis. Surabaya: Faculty of Public Health, Universitas Airlangga.

Arfiasari, A. D. (2014) Hubungan Postur Kerja dengan Keluhan Muskuloskeletal dan Produktivitas Kerja pada Pekerja Bagian Pengepakan di PT. Djitoe Indonesia Tobako. Undergraduate Thesis. Surakarta: Faculty of Health Sciences, Universitas Muhammadiyah Surakarta.

Bureau of Labor Statistics (2016) Nonfatal Occupational Injuries and Illnesses Requiring Days Away from Work. United State of America: Department of Labor. 
Jalajuwita, R. N. and Paskarini, I. (2015) 'Hubungan Posisi Kerja dengan Keluhan Muskuloskeletal pada Unit Pengelasan PT. X Bekasi', The Indonesian Journal of Occupational Safety and Health, 4(1), pp. 33-42.

Kamurahan, E. M., Malonda, N. S. H. and Sondakh, R. C. (2018) 'Hubungan antara Status Gizi dan Sikap Kerja dengan Keluhan Musculoskeletal pada Nelayan di Desa Kalinaun Kecamatan Likupang Timur Kabupaten Minahasa Utara', Community Health, 3(1), pp. 91-103.

Ministry of Health of the Republic of Indonesia (2009) Profil Kesehatan Indonesia 2008.

Nareshwari (2017) Hubungan Posisi Kerja dengan Keluhan Muskuloskeletal pada Pekerja Perawatan Sumur Minyak di PT. Pertamina EP Asset 2 Prabumulih Field. Undergraduate Thesis. Surabaya: Faculty of Public Health, Universitas Airlangga.

Rahayu, W. A. (2012) 'Faktor-faktor yang Berhubungan dengan Keluhan Muskuloskeletal pada Pekerja Angkat-angkut Industri Pemecahan Batu di Kecamatan Karangnongko Kabupaten Klaten', Jurnal Kesehatan Masyarakat FKM Universitas Diponegoro, 1(2), pp. 836-844.

Sari, E. N., Handayani, L. and Saufi, A. (2017) 'Hubungan Antara Umur dan Masa Kerja dengan Keluhan Musculoskeletal Disorders (MSDs) pada Pekerja Laundry', Jurnal Kedokteran dan Kesehatan, 13(2), pp. 183-193.
Septiani, A. (2017) Faktor-faktor yang Berhubungan dengan Keluhan Musculoskeletal Disorders (MSDs) pada Pekerja bagian Meat Preparation PT. Bumi Sarimas Indonesia Tahun 2017, Jakarta. Undergraduate Thesis. Jakarta: Faculty of Medicine and Health Sciences, Universitas Islam Negeri Syarif Hidayatullah.

Tarwaka (2015) Ergonomi Industri Dasar-Dasar Pengetahuan Ergonomi dan Aplikasi di Tempat Kerja. Surakarta: Harapan Press.

Tarwaka, Bakri, S. and Sudiajeng, L. (2004) Ergonomi untuk Keselamatan, Kesehatan Kerja dan Produktivitas. Surakarta: Uniba Press.

Umami, A. R., Hartanti, R. I. and Sujoso, A. D. P. (2014) 'Hubungan antara Karakteristik Responden dan Sikap Kerja Duduk dengan Keluhan Nyeri Punggung Bawah (Low Back Pain) Pada Pekerja Batik Tulis', Pustaka Kesehatan, 2(1), pp. 72-78.

Zar, A. (2012) Faktor-Faktor yang Berhubungan dengan Keluhan Muskuloskeletal pada Upper Limb Extremities Mahasiswa Ketika Proses Belajar Mengajar di Kelas di Fakultas Kedokteran dan Ilmu Kesehatan Universitas Islam Negeri Syarif Hidayatullah Jakarta Tahun 2012. Undergraduate Thesis. Jakarta: Fakultas Faculty of Medicine and Health Sciences, Universitas Islam Negeri Syarif Hidayatullah. 